\title{
ЗАБЕЗПЕЧЕННЯ ПРАВ, СВОБОД І ЗАКОННИХ ІНТЕРЕСІВ УЧАСНИКІВ КРИМІНАЛЬНОГО ПРОВАДЖЕННЯ ПІД ЧАС ЗАСТОСУВАННЯ TEXНIЧНИХ ЗАСОБIB
}

\author{
СЕМЕНЕНЕНКО Денис - аспірант кафедри кримінально-правових \\ дисциплін юридичного факультету Харківського національного університету \\ імені В. Н. Каразіна \\ УДК 343.1 \\ https://orcid.org/0000-0001-8680-9692; \\ DOI:10.32782/NP.2020.2.19
}

В статье рассматривается проблематика обеспечения прав, свобод и законных интересов участников уголовного судопроизводства при применении технических средств.

Необходимость научного анализа прочессуальных гарантий на этапе уголовного производства обусловлена тем, ито уголовное производство в наибольшей степени сопряжено с ограничением конституционнъхх прав человека на свободу и личную неприкосновенность, неприкосновенность жилища или иного владения лица, тайну его переписки, телефонных разговоров, телеграфной и другой корреспондениии, невмешательство в личную и семейную жизнь и тому подобное.

Научнъй анализ совокупности гарантий прав и свобод личности в сфере применения технических средств в уголовном производстве должен бъть направлен на совершенствование научного видения существующей системъ процессуальных гарантий в иелом и предоставление практических рекомендаций по совершенствованию действующего уголовного прочессуального законодательства.

Формирование предложений по совершенствованию действующей нормативно-правовой базы должно реализовъгваться на основании детального анализа действующих норм законодательства по вопросам применения технических средств в уголовном производстве путем определения основнъих проблемнъих моментов, связаннъхх с несовершенством положений как КПК Украинъ так и других законов и подзаконнъих актов.
Ключевъе слова: технические средства, процессуальные гарантии, биксачия хода и результатов негласных следственных (розыскнылх) действий, уголовное преступление, специальнье устройства, прочессуальнье действия, уголовное производство.

\section{Вступ}

Завданням правосуддя в державі 6 захист прав та свобод людини і громадянина на засадах верховенства закону та справедливості.

Зважаючи на викладене, одним із основних напрямків розвитку кримінального судочинства, його основною проблемою 6 створення такого правового механізму регулювання кримінально-процесуальної діяльності, пов'язаної з порушенням, розслідуванням, розглядом і вирішенням кримінальних справ, при якому максимально забезпечувався захист законних прав індивіда $[1$, c. 8$]$.

В останні роки в Україні проводиться реформування кримінальної юстиції з позицій подальшої демократизації, гуманізації, охорони прав і свобод людини, відповідно до вимог міжнародних актів і зобов'язань України. Кримінальне процесуальне законодавство зазнало змін, які були спрямовані на реалізацію вимог Конвенції про захист прав людини і основоположних свобод. Зокрема, це стосувалося забезпечення прав учасників кримінального судочинства, розширення змагальності сторін, прав потерпілого, усунення обвинувального ухи- 
лу в діяльності суду, розширення судового контролю за обмеженням конституційних прав і свобод людини на досудовому слідстві і оскарженні рішень органу, що проводить досудове розслідування, слідчого і прокуроpa [2, с. 130].

Реформування кримінального процесуального законодавства України має на меті створення такої моделі кримінального процесу, зокрема, його досудових стадій, яка дозволила 6 забезпечити ефективність досудового розслідування при високому рівні правової захищеності його учасників, що виключає можливість незаконного й необгрунтованого обмеження їх прав і свобод. Збалансованість суспільних інтересів і інтересів окремих громадян, визначення чітких меж та умов втручання державних органів у сферу приватного життя осіб, які залучаються до участі в кримінальному процесі, - пріоритетні напрямки розвитку кримінального процесуального законодавства і правової науки. Від вирішення цієї проблеми залежать не тільки техніко-юридичний зміст чинного законодавства, а й його соціальна спрямованість. Виходячи з цього, права й інтереси окремої людини набувають публічного характеру, оскільки стають суспільною цінністю [3, с. 3].

Проблема прав людини взагалі й у сфері кримінального судочинства, зокрема, а також гарантій їх забезпечення, в тому числі засади кримінального процесу, незмінно належить до тих, які привертають увагу вчених багатьох поколінь. Рівень іiі наукового розроблення відбиває соціально-політичне становище в державі та світоглядні уявлення, що панують у суспільстві.

\section{Огляд праць 3 даної проблематики}

Значний внесок у висвітлення цієї проблеми зробили відомі юристи: П.І. Аюблінський, М.М. Розін, В.К. Случевський,I.Я. Фойницький. У сучасний період окремі аспекти механізму реалізації й захисту конституційних прав людини в царині кримінального судочинства, зокрема на досудовому провадженні, стали предметом наукових досліджень Ю.П. Аленіна, С.А. Альперта, Ю.М. Грошевого, М.В. Джиги, В.С. Зеленецького, О.В. Капліної, В.О. Конова- лової, Є.Д. Аук'янчикова, В.I. Мариніва,М . М . М а р к уш, А. Р . М и х ай ле н ка, М.М.Михеєнка, В.Т. Нора,- М.I. Сірого, C.M. Стахівського, В.M. Трофименка,А.Р. Туманянц, Д.В. Філіна, В.Д. Фінька, Г.І. Чангулі, А.Д. Удалової, О.Г. Шило,M.Е. Шумило та інших учених.

Разом $з$ тим, існуе ряд проблем теоретичного характеру, які до цього часу не були вирішені остаточно.

\section{Виклад основного матеріалу}

Досліджуючи питання гарантій забезпечення прав, свобод і законних інтересів учасників кримінального провадження, слід зазначити, що конституційні права та свободи, які належать людині від народження, 6 основними структурними елементами конституційного статусу особи. Вони становлять підвалини іiі правового статусу, закріплені в конституції держави й мають найвищий юридичний захист. Конституція України визначає систему основоположних прав людини, які є невід'ємними, невідчужуваними й непорушними й у своєму взаємозв'язку визначають цілісність цього статусу у сфері кримінально-процесуальної діяльності. Саме в цій системі вони утворюють фундамент сучасного буття людини в демократичній правовій державі.

Особливого значення в такому контексті набуває вирішення питання стосовно допустимості обмеження конституційних прав особи в кримінальному судочинстві, визначення його меж і підстав.

На думку Д.С. Кутоманова, таке обмеження може бути визнане правомірним лише за наявності наступних умов [3, с. 10]:

(a) якщо його можливість передбачена законом;

(б) якщо ним досягається мета забезпечити визначені законом суспільні інтереси, пов'язані зі встановленням особи, яка вчинила злочин, притягненням її до кримінальної відповідальності й відшкодуванням завданої нею шкоди;

(в) якщо обмеження права (як неодноразово зазначав у своїх рішеннях Европейський суд з прав людини) домірне суспільно значущим цілям. 


\section{Кримінальне право, кримінальний процес та криміналістика}

На думку О.А. Струць, процесуальна дія буде законною за умови дотримання таких вимог: наявність в органу чи особи повноважень провадити відповідні процесуальні дії щодо певної особи та в конкретний момент; дотримання встановленого законом порядку прийняття рішення про проведення певної дії; наявність фактичних підстав для прийняття цього рішення; забезпечення визначеного КПК порядку провадження дій; належна процесуальна фіксація перебігу та результатів дії [4, с. 9-10].

Як відомо, кримінальний процес є способом державного захисту прав людини не тільки від кримінальних правопорушень, а й від зловживань державою з боку власної репресивної влади. Відтак існує необхідність установлення таких кримінально-процесуальних гарантій прав особи, які унеможливлювали 6 їх безпідставне обмеження, а при його допущенні забезпечували б їх негайне поновлення й відшкодування завданої у зв'язку із цим шкоди.

Так, метою процесуальної регламентації підстав і порядку проведення кожної процесуальної дії є забезпечення, по-перше, допустимості та достовірності отриманих доказів, по-друге, прав і свобод ії учасників. Норми КПК не лише оптимальним чином врегульовують кримінальне судочинство, а й визначають межі максимально допустимих обмежень конституційних прав та свобод учасників процесу під час проведення процесуальних дій [4, с. 9].

Процесуальні гарантії в кримінальному судочинстві існують як єдність процесуальних норм, що регламентують права та обов'язки учасників кримінального судочинства, та діяльності, спрямованої на реалізацію цих норм [4, с. 8].

У сучасній теорії права, як правило, під юридичними гарантіями розуміють умови i засоби, які забезпечують фактичну реалізацію та всебічну охорону прав і свобод усіх $\mathrm{i}$ кожного [5, с. 113].

М.С. Строгович гарантіями кримінального судочинства визнав встановлені законом засоби, за допомогою яких охороняються та забезпечуються права та законні інтереси осіб, які беруть участь у кримінальному процесі [6, с. 56].
М.М. Михеєнко дав подібне визначення: «Процесуальні гарантії - це передбачені законом засоби забезпечення завдань кримінального судочинства й охорони прав i законних інтересів осіб, які беруть у ньому участь». До них він відносить процесуальну форму, принципи кримінального процесу, процесуальні обов'язки його суб'єктів і заходи кримінально-процесуального примусу [7, с. 32].

ᄉ.M. Аобойко називає кримінальнопроцесуальними гарантіями «визначені процесуальним законом засоби забезпечення ефективного функціонування кримінального процесу» та подає свою, більш розгалужену, систему цих гарантій, до якої входять: достатній ступінь урегульованості кримінально-процесуальної діяльності; кримінально-процесуальна форма; принципи кримінального процесу; процесуальний статус учасників кримінального процесу; можливість застосування заходів кримінально-процесуального примусу (запобіжних та інших заходів); судовий контроль; прокурорський нагляд; відомчий контроль; обгрунтування процесуальних рішень i ускладнений порядок прийняття деяких iз них (про обшук у житлі особи, про взяття особи під варту тощо); право на оскарження дій і рішень органів та посадових осіб, які ведуть процес; юридична відповідальність [8, с. 19].

В.М. Тертишник пропонує інший підхід до системи кримінально-процесуальних гарантій, поділяючи іiі на три групи, до яких відносить «гарантії правосуддя», «гарантії встановлення об'єктивної істини» та «гарантії захисту прав і свобод людини» [9, с. 25]. На його думку, гарантіями встановлення об'єктивної істини виступає як процесуальна форма в цілому, так і окремі інститути кримінального процесу: принципи кримінального процесу, доказове право, інститути слідчих (розшукових) дій, інститут судового слідства і судових дебатів тощо.

До процесуальних гарантій прав та законних інтересів кримінального судочинства він включає наступні елементи: юридичне визначення самих прав і свобод; недопустимість звуження сучасних прав i свобод як за обсягом, так і за змістом; визна- 
чення процедури їх реалізації; надання реальної можливості для самореалізації; утримання від порушень прав і свобод з боку інших учасників процесу; надання допомоги з боку слідчого, органу, що проводять досудове розслідування, прокурора, захисника і суду в реалізації прав і свобод та покладення обов'язку здійснення заходів щодо їх попередження на осіб, які ведуть кримінальне судочинство чи виконують функцію процесуального контролю й нагляду; захист прав і свобод - встановлення перешкод, які б виключали їх порушення; відновлення порушених прав і свобод; повну реабілітацію й відшкодування завданої шкоди [9, с. $328-$ 329].

Системою гарантій правосуддя, як зауважує В.М. Тертишник, є оптимальне співвідношення гарантій встановлення істини і гарантій захисту прав і свобод особи [10, с. 26].

Викладене дозволяє дійти висновку про те, що до правових засобів, які утворюють систему кримінально-процесуальних гарантій, належать основні засади кримінального процесу, кримінально-процесуальна форма, права й обов'язки суб'єктів кримінальнопроцесуальної діяльності, передбачені законом строки проведення процесуальних дій і прийняття процесуальних рішень. Системна дія цих гарантій забезпечує досягнення поставленої мети - вирішення завдань кримінального судочинства, що може розглядатися як інтегративна якість усієї системи.

Сучасні автори часто поділяють кримінально-процесуальні гарантії на 2 групи - гарантії правосуддя й гарантії прав і законних інтересів особи [3, с. 11]. При цьому, Д.С. Кутоманов підкреслює умовний характер вищенаведеної класифікації, бо з урахуванням конституційних положень щодо цінності людини, їі життя і здоров'я, честі й гідності гарантії прав особи апріорі набувають значення гарантій правосуддя як напрямку державної діяльності, що є способом захисту прав і свобод людини [3, с. 11].

Існують також і інші наукові підходи до питання класифікації кримінально-процесуальних гарантій. Так, О.А. Струць стверджує, що окремий правовий засіб як процесуальну гарантію можливо визначити лише в межах конкретних або кількох однорідних правовідносин. Підтримуючи думку про відкритість системи процесуальних гарантій, О.А. Струць класифікує всі процесуальні гарантії, що застосовуються у сфері кримінального судочинства, за юридичною силою їх джерела, за трьома групами: 1) міжнародно-правові; 2) конституційні; 3) спеціальні (охоплюють норми кримінального процесуального та інших галузей права) [4, с. 8].

Більшість сучасних науковців цілком виправдано сходиться на тому, що всі кримінально-процесуальні гарантії взаємопов'язані між собою, утворюють єдину, нерозривну цілісність. Е.Ф. Куцова зауважила, що взаємопов'язаність розглядуваних гарантій слугує забезпеченню їх реальності; приводить до того, що вони $\epsilon$ не розрізненою сумою засобів, а системою кримінально-процесуальних гарантій прав та законних інтересів учасників судочинства, які взаємопідкріплюють одна одну [12, c. 128].

M.I. Капінус щодо цього зазначає, що передумова взаємодії окремих елементів системи процесуальних гарантій - єдина цільова спрямованість правового поля їх дії, тобто призначення кримінального судочинства. Основою ж взаємодії є багатофункціональний характер процесуальних гарантій, їх здатність одночасно забезпечувати рішення як основних, так і допоміжних завдань. I хоча кожна процесуальна гарантія має власне цільове призначення, у сукупності всі вони за допомогою охорони та захисту прав особи забезпечують досягнення кримінального судочинства. Система процесуальних гарантій, як визначає M.I. Капінус, - це органічна цілісність процесуальних засобів та способів, які взаємодіють між собою при забезпеченні прав та законних інтересів учасників кримінального судочинства 3 метою реалізації призначення кримінального судочинства [13, c. 121-122].

Т.Г. Фоміна надала визначення системи процесуальних гарантій як сукупності встановлених законом засобів, що взаємодіють між собою при виконанні завдань кримінального судочинства, забезпечують правильне здійснення правосуддя у кримінальних справах та реалізацію прав і виконання 


\section{Кримінальне право, кримінальний процес та криміналістика}

обов’язків усіма учасниками кримінального процесу [14, с. 187].

На думку В.А. Савченка, це означає, що права та законні інтереси не можуть бути забезпечені без виконання всього комплексу завдань кримінального судочинства, оскільки невиконання одного завдання неминуче потягне за собою невиконання іншого [15, c. 280].

Викладене дозволяє нам припустити факт існування певних сукупностей процесуальних гарантій, які можуть розглядатися у своїй цілісності як окремі підсистеми загальної системи кримінально-процесуальних гарантій.

Так, О.ภ. Булейко звертає увагу на існування певних норм, що носять конституційний характер, оскільки є спрямованими на захист таких важливих цінностей, як честь і гідність, особиста і сімейна таємниця та при цьому за змістом закону вони повинні застосовуватися лише при тих слідчих діях, проведення яких вони регулюють [2, с. 130].

С.О. Бандурка, досліджуючи проблематику відсутності механізму процесуальних процедур, які пов'язані із забезпеченням правових гарантій у цілому у кримінальному процесі, разом з тим, виокремлює певні групи правовідносин, для яких є характерними ті чи інші недоліки [16, с. 33-36].

C.I. Перепелиця досліджував специфіку кримінально-процесуальних гарантій, притаманних забезпеченню прав та свобод учасників провадження по справах приватного обвинувачення шляхом реалізації диспозитивних і публічних засад кримінального судочинства [17, с. 722-727].

M.I. Капінус розглянув процесуальні гарантії прав особи при застосуванні примусових заходів у кримінальному процесі [13].

Ю.М. Бєлозьоров та П.Г. Марфіцин обрали як об'єкт наукового аналізу забезпечення прав та законних інтересів особи на етапі порушення справи [18].

Викладене дозволяє дійти висновку про необхідність дослідження системи процесуальних гарантій у розрізі певних етапів кримінального процесу, що, у кінцевому підсумку, дозволить більш повно провести науковий аналіз усієї системи процесуальних гарантій.
При цьому ми вважаємо, що, у першу чергу, існує необхідність наукового аналізу процесуальних гарантій у розрізі кримінального провадження.

Наша позиція обумовлена тим, що кримінальне провадження найбільшою мірою поєднане 3 обмеженням конституційних прав людини на свободу й особисту недоторканість, недоторканність житла чи іншого володіння особи, таємницю ії листування, телефонних розмов, телеграфної й іншої кореспонденції, невтручання в особисте й сімейне життя тощо. Адже саме в цій стадії кримінального процесу застосовуються заходи кримінально-процесуального примусу. Цим пояснюється очевидна потреба створення дієвого механізму захисту прав i законних інтересів осіб, які беруть участь у провадженні по справі незалежно від процесуального статусу останніх.

\section{Висновки}

Разом 3 тим, досліджуючи систему процесуальних гарантій у розрізі кримінального провадження, маємо звернути увагу на існування особливостей процесуальної форми і специфіку завдань, характерних для застосування технічних засобів.

1. Як відомо, законність є визначальною засадою кримінального судочинства, оскільки стосується всіх стадій та інститутів кримінального процесу. Тому лише за умови неухильного дотримання вимог закону при застосуванні технічних засобів у кримінальному провадженні створюються умови для реалізації всієї системи процесуальних гарантій прав та свобод особи.

2. Застосування технічних засобів у кримінальному провадженні найбільшою мірою поєднане 3 обмеженням конституційних прав людини на свободу й особисту недоторканість, недоторканність житла чи іншого володіння особи, таємницю їі листування, телефонних розмов, телеграфної й іншої кореспонденції, невтручання в особисте й сімейне життя тощо.

3. Виходячи із сутності кримінального судочинства як засобу захисту прав людини, особливого значення набуває належна правова регламентація порядку застосування технічних засобів на його початковій стадії. 
Останній має включати як відповідні засоби, що забезпечують подальше ефективне провадження за наявності законних приводів, підстав і захист законних інтересів особи, яка постраждала від злочину, так і механізми, які унеможливлюють безпідставне обмеження конституційних прав осіб, не причетних до вчиненого злочину [3, с. 11].

4. Норми КПК мають врегульовувати оптимальним чином не лише питання застосування технічних засобів у кримінальному провадженні, а й визначати межі максимально допустимих обмежень конституційних прав та свобод учасників процесу під час проведення тих чи інших дій.

5. Обгрунтованість процесуальних рішень визначається специфікою підстав для ïх прийняття. Зважаючи на це, існує необхідність чіткого закріплення у кримінальному процесуальному законодавстві правових та фактичних підстав застосування технічних засобів у кримінальному провадженні.

Викладене свідчить про виключну важливість наукового аналізу сукупності гарантій прав і свобод особи у сфері застосування технічних засобів у кримінальному провадженні для формування та удосконалення загалу наукових поглядів на сучасну систему процесуальних гарантій та надання практичних рекомендацій з удосконалення чинного кримінального процесуального законодавства.

\section{入ітература}

1. Грошевой Ю. М. Кримінальний процес : підручник / за ред. Ю. М. Грошевого та О. В. Капліної. - Х. : Право, 2010. - 608 с.

2. Булейко О. ᄉ. Забезпечення прав учасників кримінально-процесуального судочинства / О. А. Булейко // Вісник Академії адвокатури України. - 2009. - №1. - С. 130 132.

3. Кутоманов Д. Е. Забезпечення конституційних прав особи в досудовому провадженні по кримінальних справах : автореф. дис. на здобуття наук. ступеня канд. юрид. наук : спец. 12.00.09 «Кримінальний процес та криміналістика; судова експертиза; оперативно-розшукова діяльність»/Д. С. Кутоманов. - Харків, 2009. - 20 с.
4. Струць О. А. Законність та обгрунтованість проведення слідчих дій як гарантія прав і свобод учасників кримінального судочинства : автореф. дис. на здобуття наук. ступеня канд. юрид. наук : спец. 12.00.09 «Кримінальний процес та криміналістика; судова експертиза; оперативно-розшукова діяльність» / О. А. Струць. - К., 2009. - 18 с.

5. Кучинська О. П. Гарантії забезпечення захисту прав учасників кримінального провадження / О. П. Кучинська // Вісник Академії адвокатури України. - 2012. - №1. - C. 112-116.

6. Строгович М. С. Курс советского уголовного процесса : [в 2-х т.] / М.С. Строгович. - М. : Наука, 1970. - 516 с.

7. Михеєнко М. М. Кримінальний процес України : [підручник] / Михеєнко М. М., Нор В. Т., Шибіко В. П. - (2-ге вид., перероб. і доп.). - К. : Аибідь, 1999. - 536 с.

8. Лобойко $\lambda$. Кримінальнопроцесуальне право / $\Lambda$. Аобойко. - К., Істина, 2005. - 350 c.

9. Тертишник В. М. Гарантії істини та захисту прав і свобод людини в кримінальному процесі : [монографія] / В.М. Тертишник. Д. : Юрид. акад. МВС України, Арт-Прес, 2002. - 432 с.

10. Тертишник В. М. Кримінальнопроцесуальне право України : [підруч.]. 4-те вид., доп. і переробл. / В. М. Тертишник. К. : Видавництво А.С.К., 2003. - 1120 с.

11. Тертышник В. М. Защита прав и свобод человека : [научно-практическое издание] / Тертышник В. М., Марченко А. В., Тертышник А. И. - Харьков : Арсис, 2000. -288 c.

12. Куцова Ә. Ф. Гарантии прав личности в советском уголовном процессе /Э. Ф. Куцова. - М. : Юрид. лит., 1973. - 200 с.

13. Капинус Н. И. Процессуальные гарантии прав личности при применении мер пресечения в уголовном процессе : монография / Н. И. Капинус. - М.: Буквовед, 2007. - 416 c.

14. Фоміна Т. Г. Дискусійні питання щодо визначення системи кримінальнопроцесуальних гарантій / Т. Г. Фоміна // Право і безпека. - 2010. - №5. - С. 185-188. 


\section{Кримінальне право, кримінальний процес та криміналістика}

15. Савченко В. А. Кримінальнопроцесуальні гарантії (за законодавством України) / В. А. Савченко // Прикарпатський юридичний вісник. - 2011. - №1. -C. 278-288.

16. Бандурка С. О. Теорія та практика процесуальних гарантій у кримінальному процесі / С. О. Бандурка // Форум права. 2010. - №4. - С. 33-36.

17. Перепелиця С. I. Забезпечення прав та свобод учасників провадження по справах приватного обвинувачення шляхом реалізації диспозитивних і публічних засад кримінального судочинства: теоретичний аспект / C. I. Перепелиця // Форум права. 2011. - №2. - С. 722-727.

18. Белозеров Ю. Н. Обеспечение прав и законных интересов личности в стадии возбуждения уголовного дела / Ю. Н. Белозеров, П. Г. Марфицын. - М.: Наука, 1994. $-104 \mathrm{c}$.

\section{References}

1. Groshevoj Ju. M. Kriminal'nij proces: pidruchnik / za red. Ju. M. Groshevogo taO. V. Kaplinoï. - H. : Pravo, 2010. - 608 s.

2. Bulejko O. L. Zabezpechennja prav uchasnikiv kriminal'no-procesual'nogo sudochinstva / O. L. Bulejko // Visnik Akademiï advokaturi Ukraïni. - 2009. - №1. - S. 130-132.

3. Kutomanov D. E. Zabezpechennja konstitucijnih prav osobi $\mathrm{v}$ dosudovomu provadzhenni po kriminal'nih spravah : avtoref. dis. na zdobuttja nauk. stupenja kand. jurid. nauk : spec. 12.00.09 «Kriminal'nij proces ta kriminalistika; sudova ekspertiza; operativno-rozshukova dijal'nist'» / D. E. Kutomanov. - Harkiv, 2009. - 20 s.

4. Struc' O. A. Zakonnist' ta obrruntovanist' provedennja slidchih dij jak garantija prav i svobod uchasnikiv kriminal'nogo sudochinstva : avtoref. dis. na zdobuttja nauk. stupenja kand. jurid. nauk : spec. 12.00.09 «Kriminal'nij proces ta kriminalistika; sudova ekspertiza; operativno-rozshukova dijal'nist'» / O. A. Struc'. - K., 2009. - 18 s.

5. Kuchins'ka O. P. Garantiï zabezpechennja zahistu prav uchasnikiv kriminal'nogo provadzhennja / O. P. Kuchins'ka // Visnik Akademiï advokaturi Ukraïni. - 2012. - №1. - S. 112-116.
6. Strogovich M. S. Kurs sovetskogo ugolovnogo processa : [v 2-h t.] / M.S. Strogovich. - M. : Nauka, 1970. - 516 s.

7. Miheenko M. M. Kriminal'nij proces Ukraïni : [pidruchnik] / Miheєnko M. M., Nor V. T., Shibiko V. P. - (2-ge vid., pererob. i dop.). - K. : Libid', 1999. - 536 s.

8. Lobojko L. Kriminal'no-procesual'ne pravo / L. Lobojko. - K., Istina, 2005. - 350 s.

9. Tertishnik V. M. Garantiï istini ta zahistu prav i svobod ljudini v kriminal'nomu procesi: [monografija] / V.M. Tertishnik. - D.: Jurid. akad. MVS Ukraïni, Art-Pres, 2002. - 432 s.

10. Tertishnik V. M. Kriminal'noprocesual'ne pravo Ukraïni : [pidruch.]. 4-te vid., dop. i pererobl. / V. M. Tertishnik. - K. : Vidavnictvo A.S.K., 2003. - 1120 s.

11. Tertyshnik V. M. Zashhita prav i svobod cheloveka : [nauchno-prakticheskoe izdanie] / Tertyshnik V. M., Marchenko A. V., Tertyshnik A. I. - Har'kov : Arsis, 2000. - 288 s.

12. Kucova Je. F. Garantii prav lichnosti v sovetskom ugolovnom processe / Je. F. Kucova. - M. : Jurid. lit., 1973. - 200 s.

13. Kapinus N. I. Processual'nye garantii prav lichnosti pri primenenii mer presechenija v ugolovnom processe : monografija /N. I. Kapinus. - M.: Bukvoved, 2007. - 416 s.

14. Fomina T. G. Diskusijni pitannja shhodo viznachennja sistemi kriminal'noprocesual'nih garantij / T. G. Fomina // Pravo i bezpeka. - 2010. - №5. - S. 185-188.

15. Savchenko V. A. Kriminal'noprocesual'ni garantiï (za zakonodavstvom Ukraïni) / V. A. Savchenko // Prikarpats'kij juridichnij visnik. - 2011. - №1. - S. 278-288.

16. Bandurka S. O. Teorija ta praktika procesual'nih garantij u kriminal'nomu procesi / S. O. Bandurka // Forum prava. 2010. - №4. - S. 33-36.

17. Perepelicja S. I. Zabezpechennja prav ta svobod uchasnikiv provadzhennja po spravah privatnogo obvinuvachennja shljahom realizaciï dispozitivnih i publichnih zasad kriminal'nogo sudochinstva: teoretichnij aspekt / S. I. Perepelicja // Forum prava. - 2011. - №2. - S. 722-727.

18. Belozerov Ju. N. Obespechenie prav i zakonnyh interesov lichnosti v stadii vozbuzhdenija ugolovnogo dela / Ju. N. Belozerov, P. G. Marficyn. - M.: Nauka, 1994. - 104 s. 


\section{АНОТАЦІЯ}

В статті розглядається проблематика забезпечення прав, свобод і законних інтересів учасників кримінального провадження під час застосування технічних засобів.

Необхідність наукового аналізу процесуальних гарантій на етапі кримінального провадження обумовлена тим, шо кримінальне провадження найбільшою мірою поєднане 3 обмеженням конституційних прав людини на свободу й особисту недоторканість, недоторканність житла чи іншого володіння особи, таємницю ї̈ листування, телебонних розмов, телеграфбної й іншої кореспондениіи, невтручання в особисте й сімейне життя тощо.

Науковий аналіз сукупності гарантій прав i свобод особи у сбері застосування технічних засобів у кримінальному провадженні має бути спрямований на удосконалення наукового бачення існуючої системи процесуальних гарантій у изілому та надання практичних рекомендацій з удосконалення чинного кримінального процесуального законодавства.

Формування пропозииій щодо удосконалення чинної нормативно-правової бази має реалізовуватися на підставі детального аналізу чинних норм законодавства з питань застосування технічних засобів у кримінальному провадженні шляхом визначення основних проблемних моментів, пов'язаних із недосконалістю положень як КПК Украӥни так $i$ iнших законів та підзаконних актів.

Ключові слова: технічні засоби, прочесуальні гарантї, біксація ходу і результатів негласних слідчих (розшукових) дій, кримінальне правопорушення, спеціальні пристрої, прощесуальні дї, кримінальне провадження.

\section{Semenenenko Denis \\ ENSURING THE RIGHTS, FREEDOMS AND LEGAL INTERESTS OF PARTICIPANTS IN GRIMINAL PROCEEDINGS DURING THE APPLICATION OF TECHNICAL MEANS}

The article deals with the problems of ensuring the rights, freedoms and legitimate interests of participants in criminal proceedings when using technical means.

The need for a scientific analysis of procedural guarantees at the stage of criminal proceedings is due to the fact that criminal proceedings are most closely associated with the restriction of the constitutional human rights to freedom and personal inviolability, the inviolability of the home or other property of a person, the secrecy of his correspondence, telephone conversations, telegraph and other correspondence, non-interference in personal and family life and the like.

Scientific analysis of the totality of guarantees of individual rights and freedoms in the field of using technical means in criminal proceedings should be aimed at improving the scientific vision of the existing system of procedural guarantees in general and providing practical recommendations for improving the current criminal procedural legislation.

Formulation of proposals to improve the current regulatory framework should be implemented on the basis of a detailed analysis of the current legislation on the use of technical means in criminal proceedings by identifying the main problem points associated with the imperfection of the provisions of the Criminal Procedure Code of Ukraine and other laws and regulations.

Key words: technical equipment, procedural guarantees, fixing the progress and results of covert investigative (search) actions, criminal offense, special devices, procedural actions, criminal proceedings. 